\title{
ERRATUM
}

Boo-Keun Khim • Hee Mdn Jung • Daekyo Cheong

\section{Recent variations in sediment organic carbon content in Lake Soyan (Korea)}

\section{Limnology (2005) 6:61}

An error appeared on page 61 of this issue of the journal. The name of the second author was incorrectly shown as:

Hee Mdn Jung

The correct name is the following:

Hee Man June

The publisher sincerely apologizes for this error.

B.-K. Khin $(\bowtie)$

Department of Marine Science, Pusan National University, Pusan 609-735, Korea

Tel. +82-51-510-2212; Fax +82-51-581-2963

e-mail: bkkhin@psan.ac.kr

H.M. Jung · D. Cheong

Department of Geology, Kangwon National University, Chuncheon,

Korea 